CLINICAL PRACTICE Clinical Vignettes

\title{
Bromism in the Modern Day: Case Report and Canadian Review of Bromide Intoxication
}

\author{
Christina S. Thornton, MD, $\mathrm{PhD}^{1,2}$ (1) and Jolene T. Haws, $\mathrm{MD}^{1}$ \\ 'Department of Medicine, University of Calgary, Calgary, Alberta, Canada ; '2Division of Respirology, University of Calgary, Calgary, Alberta, Canada .
}

$\mathrm{J}$ Gen Intern Med 35(8):2459-61

DOI: $10.1007 / \mathrm{s} 11606-020-05907-\mathrm{x}$

(C) Society of General Internal Medicine 2020

\section{CASE PRESENTATION}

A 70-year-old man presented to hospital with a 2-week history of anorexia, abdominal discomfort, and constipation. The patient described the abdominal pain as cramping in nature, radiating bilaterally to the flanks with associated nausea and constipation during this timeframe. He complained of general malaise and reported a headache. His family added that for 2 weeks, his level of consciousness was significantly altered from his baseline, including confusion and word-finding difficulties.

The patient's previous medical diagnoses included stage III chronic kidney disease secondary to ischemic nephropathy and chronic nonsteroidal anti-inflammatory drug (NSAIDs) use, hypertension, dyslipidemia, osteopenia, and gastric esophageal reflex disease (GERD). The patient also had a history of chronic headaches, which had been extensively investigated by neurology and attributed to migraine attacks. The patient's medications included atenolol $12.5 \mathrm{mg}$ daily, atorvastatin $10 \mathrm{mg}$ daily, venlafaxine $225 \mathrm{mg}$ daily, ibuprofen 400-800 mg once to twice daily as needed, and an over-thecounter Japanese supplement daily. During flares of his headache, he took NSAIDs and additional doses of the over-thecounter Japanese supplement. He took this supplement daily ( 1 tablet of an unknown quantity and name) for a minimum of 10 years prior to presentation.

On physical examination, the patient's body temperature was elevated at $38.7{ }^{\circ} \mathrm{C}$, heart rate was 118 beats $/ \mathrm{min}$, and blood pressure was 161/88 $\mathrm{mmHg}$. He was disorientated and agitated with a Glasgow coma scale (GCS) of 12 (eyes 4, verbal 3, motor 5). Respiratory, cardiovascular, abdominal, and dermatological examinations were within normal limits. Neurological examination was significant for confusion, agitation, and the inability to follow commands. Bilateral clonus of 4-to- 5 beats was observed in the lower extremities with a right-sided upper extremity action tremor and spreading of the patellar reflexes to the contralateral leg. The remainder of the

Received November 7, 2019

Accepted May 4, 2020

Published online May 18, 2020 neurological examination including cranial nerves, motor, sensation, tone, and cerebellar were normal.

A review of the patient's medical records revealed a persistent hyperchloremia (chloride $>175 \mathrm{mmol} / \mathrm{L}$, reference range $98-111 \mathrm{mmol} / \mathrm{L}$ ) for the preceding 10 years of unclear etiology. Coincident with this was mention of a negative anion gap $(-6.3 \mathrm{mmol} / \mathrm{L}$; reference range $4-16 \mathrm{mmol} / \mathrm{L})$ with a $\mathrm{pH}$ within normal limits (reference range 7.36-7.44). On this hospital admission, laboratory investigations showed a markedly elevated chloride level of $>175 \mathrm{mmol} / \mathrm{L}$ (reference range $98-111 \mathrm{mmol} / \mathrm{L})$ with a negative anion gap $(-7.8 \mathrm{mmol} / \mathrm{L}$; reference range $4-16 \mathrm{mmol} / \mathrm{L}$ ). Table 1 shows the complete results of investigations.

Review of the supplement's ingredients revealed it contained ibuprofen, ethenzamide, caffeine, and bromovaleryl urea. Following the identification of active ingredients within the Japanese supplement, the patient was started on normal saline and supportive medical care. He had a rapid clinical improvement in both clinical and biochemical parameters. At time of discharge, his confusion and neurologic abnormalities had completely resolved. The chloride level was $105 \mathrm{mmol} / \mathrm{L}$ (reference range $98-111 \mathrm{mmol} / \mathrm{L}$ ) with a normal anion gap of $8 \mathrm{mmol} / \mathrm{L}$ (reference range $4-16 \mathrm{mmol} / \mathrm{L}$ ). The patient's hyperchloremia was determined to be pseudohyperchloremia due to a laboratory testing abnormality from the elevated levels of bromide in his blood. A plasma bromide level drawn on admission returned several weeks later and was found to be $>100 \mathrm{mg} / \mathrm{dL}$ (reference range $0.3-1.2 \mathrm{mg} / \mathrm{dL}$ ). The patient was advised to discontinue this permanently and has had no further recurrence of clinical symptoms or hyperchloremia.

\section{DISCUSSION}

The use of bromide salts in therapeutic medications including anticonvulsants and sedatives began in $1826 .{ }^{1}$ Shortly thereafter, the salts were used in many over-the-counter medications such as Bromo Seltzer and Dr. Miles' Nervine ${ }^{1}$. Coincident with the popularity of the salts was the observation of patient dependence on these agents and subsequent chronic bromide intoxication, otherwise referred to as "bromism."1 With this correlation, the mainstream popularity of bromide salts waned but nevertheless speculated to be present to date in several over-the-counter agents and supplements. In literature reports over the last several years, the cases described are 
Table 1 Results of Investigations

\begin{tabular}{ll}
\hline \hline Test (units) & $\begin{array}{l}\text { Results on admission } \\
\text { (reference range** }\end{array}$ \\
\hline Hemoglobin $(\mathrm{g} / \mathrm{L})$ & $136(137-180)$ \\
Mean corpuscular volume & $96(82-100)$ \\
Platelets $\left(10^{9} / \mathrm{L}\right)$ & $222(150-400)$ \\
Leukocyte count $\left(10^{9} / \mathrm{L}\right)$ & $4.5(4-11)$ \\
Absolute neutrophil count $\left(10^{9} / \mathrm{L}\right)$ & $3.0(2-8)$ \\
Creatinine $(\mu \mathrm{mol} / \mathrm{L})$ & $136(50-120)$ \\
Albumin $(\mathrm{g} / \mathrm{L})$ & $34(33-48)$ \\
Aspartate aminotransferase $(\mathrm{U} / \mathrm{L})$ & $45(8-40)$ \\
Alanine aminotransferase $(\mathrm{U} / \mathrm{L})$ & $20(1-60)$ \\
Bilirubin total $(\mu \mathrm{mol} / \mathrm{L})$ & $5.0(0-24)$ \\
Sodium $(\mathrm{mmol} / \mathrm{L})$ & $141(133-145)$ \\
Potassium $(\mathrm{mmol} / \mathrm{L})$ & $3.2(3.3-5.1)$ \\
Chloride $(\mathrm{mmol} / \mathrm{L})$ & $>175(98-111)$ \\
Carbone dioxide $(\mathrm{mmol} / \mathrm{L})$ & $25(21-31)$ \\
Anion gap $(\mathrm{mmol} / \mathrm{L})$ & $-63(4-16)$ \\
Magnesium $(\mathrm{mmol} / \mathrm{L})$ & $0.9(0.65-1.05)$ \\
Phosphate $(\mathrm{mmol} / \mathrm{L})$ & $1.07(0.80-1.50)$ \\
Salicylate $(\mathrm{mmol} / \mathrm{L})$ & $<0.07(0.70-1.80)$ \\
Urea $(\mathrm{mmol} / \mathrm{L})$ & $8.2(3.0-9.0)$ \\
Urine osmolality $(\mathrm{mmol} / \mathrm{kg})$ & $378(50-1200)$ \\
Urine sodium & 110 \\
Urine potassium & 23 \\
Urine chloride & 131 \\
Serum ketones & Positive \\
\hline
\end{tabular}

*Where applicable

around the use of bromide-based anticonvulsant and sedative agents such as potassium bromide and lithium bromide. ${ }^{2}$ Reports have also been published surrounding bromisoval, known as bromovalerylurea, as a hypnotic agent marketed as an over the counter in combination with nonsteroidal antiinflammatory drugs, which have been associated with bromide poisoning. ${ }^{3}$
Bromide intoxication has been described as a great mimicker of broad medical conditions, including neurologic, infectious, and psychiatric diseases owing to its non-specific presentation and rare manifestations. Most commonly, symptoms include anorexia, unintentional weight loss, and nausea. Presentations may progress to include neuropsychiatric symptoms such as confusion, ataxia, tremor, delirium, or acute psychosis. $^{2}$ Rare dermatological manifestations include bromoderma, characterized by acneiform eruptions or, less commonly, granulomatous plaques, ulcers, or bullae, usually on the face and trunk. ${ }^{4}$

A hallmark of bromide intoxication is a high serum chloride concentration with serum sodium and $\mathrm{pH}$ within the normal range. However, the actual chloride level in the blood is likely to be much closer to normal as bromide intoxication causes pseudohyperchloremia. Under standard conditions, plasma chloride concentrations are measured by coulometry with ion-selective electrode methods. Given that bromide is a negatively charged anion, it has been shown to inconsistently interfere with measured chloride levels. A small study from France highlighted the possible difference in chloride measurements $(120$ to $230 \mathrm{mEq} / \mathrm{L}$; from an initial serum standard concentration of chloride of $118 \mathrm{mEq} / \mathrm{L}$ ) from the same bromide intoxication case (concentration of $37.5 \mathrm{mEq} / \mathrm{L}$ ) due to analytical interference by different techniques such as indirect and direct potentiometry or by colorimetry. The authors concluded that this further complicates the diverse presentation of bromide intoxication. ${ }^{5}$ Pseudohyperchloremia has also been described with hyperlipidemia and salicylate poisioning. ${ }^{6,7}$

Table 2 Bromide-Containing Products and Adverse Reactions in Canada from 2009 to 2019

\begin{tabular}{|c|c|c|c|c|}
\hline Compound & Drug name & Pharmacologic category & Common adverse reactions* & $\begin{array}{l}\text { No. of } \\
\text { reactions }\end{array}$ \\
\hline Aclidinium bromide & Tudorza Genuair@ & Anticholinergic agent, long-acting & Headache, diarrhea, rhinitis, nausea & 145 \\
\hline Bromide hyoscine- $n$-butyl & Buscopan` & Anticholinergic agent & Drowsiness, dizziness, xerostomia & 59 \\
\hline Bromide pyridostigmine & Mestinon (C) & Acetylcholinesterase inhibitor & Twitching, hyperesthesia, xeroderma & 78 \\
\hline Bupropion hydrobromide & $\begin{array}{l}\text { Bupropion } ₫ \text {, } \\
\text { Wellbutrin } \bigodot\end{array}$ & $\begin{array}{l}\text { Dopamine/norepinephrine-reuptake } \\
\text { inhibitor }\end{array}$ & $\begin{array}{l}\text { Tachycardia, insomnia, headache, } \\
\text { agitation, dizziness }\end{array}$ & 3 \\
\hline Citalopram hydrobromide & $\begin{array}{l}\text { Citalopram@ } ₫ \text {, } \\
\text { Celexa@ }\end{array}$ & $\begin{array}{l}\text { Selective serotonin reuptake } \\
\text { inhibitor }\end{array}$ & $\begin{array}{l}\text { Drowsiness, diaphoresis, nausea, } \\
\text { xerostomia }\end{array}$ & 174 \\
\hline Darifenacin hydrobromide & Enablex@ & Anticholinergic agent & Xerostomia, constipation & 15 \\
\hline $\begin{array}{l}\text { Dextromethorphan } \\
\text { hydrobromide }\end{array}$ & $\begin{array}{l}\text { Buckleys@, } \\
\text { Robitussin } \bigodot\end{array}$ & $\begin{array}{l}N \text {-methyl-D-aspartate (NMDA) } \\
\text { receptor antagonist }\end{array}$ & $\begin{array}{l}\text { Dizziness, drowsiness, restlessness, } \\
\text { nausea }\end{array}$ & 536 \\
\hline Glycopyrronium bromide & Seebri Breezhaler@ & Anticholinergic agent, long-acting & $\begin{array}{l}\text { Flushing, headache, vomiting, } \\
\text { xerostomia }\end{array}$ & 459 \\
\hline Homatropine hydrobromide & Isopto Homatropine $\odot$ & Anticholinergic agent & $\begin{array}{l}\text { Edema, xerostomia, blurred vision, } \\
\text { photophobia }\end{array}$ & 23 \\
\hline Ipratropium bromide & Atrovent $\odot$ & Anticholinergic agent & Bronchitis, headache, nausea & 488 \\
\hline Manganese bromide & Mangimin $(\odot)$ & Dietary supplement, trace element & Gastrointestinal distress, nausea & 43 \\
\hline Methylnaltrexone bromide & Relistor@ & Opioid antagonist & Abdominal pain, flatulence, nausea & 11 \\
\hline Pinaverium bromide & Dicetel@ & Calcium channel antagonist & Abdominal pain, nausea, erythema & 41 \\
\hline Rocuronium bromide & Zemuron@ & Neuromuscular blocker agent & $\begin{array}{l}\text { Hypertension, transient hypotension, } \\
\text { anaphylaxis }\end{array}$ & 129 \\
\hline Tiotropium bromide & Spiriva $\odot$ & Anticholinergic agent long-acting & Xerostomia, sinusitis, palpitations & 72 \\
\hline Umeclidinium bromide & Incruse Ellipta $\odot$ & Anticholinergic agent long-acting & Tachycardia, chest pain, abdominal pain & 807 \\
\hline \multirow[t]{2}{*}{ Vortioxetine hydrobromide } & Trintellix@ & $\begin{array}{l}\text { Selective serotonin reuptake } \\
\text { inhibitor }\end{array}$ & Sexual disorder, nausea, dizziness & 7 \\
\hline & & Total reactions & & 3090 \\
\hline
\end{tabular}

*Defined as greater than $10 \%$ of adverse reactions reported 
A negative anion gap in etiologies aside from bromism is rare and reported mostly with other ingestions including iodine or lithium and monoclonal proteinemia. ${ }^{2}$ The etiology of bromism and negative anion gap is not fully elucidated; however, it is currently felt to be due to measurement modalities. Bromide ions react stronger to analyzers and thus are often incorrectly measured as chloride. Generally, serum bromide level of $5 \mathrm{mEq} / \mathrm{L}$ measures an additional $20 \mathrm{mEq} / \mathrm{L}$ of chloride ions, ${ }^{8}$ thus leading to measurement of negative anion gap.

As part of this study, a search of Vigilance Canada was completed to assess adverse reactions with bromidecontaining products. ${ }^{9}$ Data over the last 10 years (20092019) was collected with keywords including "bromide," limited to adult population ( $\geq 18$ years of age) and serious events only. With this, a total of 3090 results were obtained comprising 17 over-the-counter and prescription drugs (Table 2). The clinician must be cautious when interpreting this data as many reactions described were in context of polypharmacy and thus make it impossible to define causation. As well, many reactions described were varied across a broad spectrum and make it difficult to elucidate the offending etiology. We would suggest the use of these drugs be used with the understanding that while adverse reactions may be broad, so are those implicated with bromide intoxication. As such, this further requires high clinical acumen to identify a potential correlation and subsequent discontinuation of drug along with supportive care.

Bromide is renally excreted with an estimated 10-12 day half-life by in vitro studies. ${ }^{10}$ The mainstay of treatment includes aggressive rehydration and saline loading, which hypothetically and mechanistically enhances renal excretion. ${ }^{11}$ This has been reported with intravenous fluids $(0.45 \%$ or $0.9 \%$ normal saline) but can be changed to oral sodium at 2 to $3 \mathrm{~g}$, dosed 3 to 4 times daily and accompanied by 4 to $10 \mathrm{~L}$ of fluid with a goal of urine output of 2 to $4 \mathrm{~mL} / \mathrm{kg} / \mathrm{h}$. ${ }^{11}$ Treatment with fluids as above may be augmented with either loop or thiazide diuretics, again to enhance renal excretion. ${ }^{10}$ This has been shown to improve bromide toxicity with in vitro data showing the half-life to be reduced to less than 1 day, ${ }^{10}$ thus facilitating prompt clinical recovery. Ultimately, in refractory cases, intermittent hemodialysis may be needed. ${ }^{12}$

In conclusion, this case highlights the keen clinical acumen required to diagnose bromide toxicity when new-onset psychiatric symptoms present with hyperchloremia and a negative anion gap. Diagnosis is critical as toxicity may be completely reversible with cessation of bromide ingestion and medical management.

Acknowledgments: We thank the patient in this manuscript for granting permission to share this case.
Corresponding Author: Christina S. Thornton, MD, PhD; Department of Medicine, University of Calgary, Calgary, Alberta, Canada (e-mail: christina.thornton@ahs.ca).

Authors' Contributions CST and JTH conceptualized and designed the case report with manuscript preparation. All authors were directly involved in the care of this patient, contributed to data acquisition and interpretation, drafted the manuscript and critically revised it for important intellectual content, approved the version to be published, and agreed to be accountable for all aspects of the work. All authors contributed equally to editing and have read and approved the final manuscript.

Availability of Data and Material Not applicable.

\section{Compliance with Ethical Standards:}

Conflict of Interest: The authors declare that they do not have a conflict of interest.

Ethics Approval and Consent to Participate: Not applicable. Written consent for publication was obtained from the patient and is available for review upon request.

Consent for Publication: Written informed consent was obtained from the patient for publication of this case report and any accompanying images. A copy of the written consent is available for review by the Editor-in-Chief of this journal.

\section{REFERENCES}

1. Emmett M. Approach to the patient with a negative anion gap. Am J Kidney Dis. 2016;67(1):143-150.

2. Chegondi M, Totapally BR. Spurious hyperchloremia and negative anion gap in a child with refractory epilepsy. Case Rep Crit Care. 2016;2016:7015463.

3. Wang YT, Yang SY, Wu vC, Wu KD, Fang CC. Pseudohyperchloraemia due to bromvalerylurea abuse. Nephrol Dial Transplant. 2005;20(8):1767-1768.

4. Taylor BR, Sosa R, Stone WJ. Bromide toxicity from consumption of dead sea salt. Am J Med. 2010;123(3):e11-12.

5. Danel VC, Saviuc PF, Hardy GA, Lafond JL, Mallaret MP. Bromide intoxication and pseudohyperchloremia. Ann Pharmacother. 2001;35(3):386-387.

6. Graber ML, Quigg RJ, Stempsey WE, Weis S. Spurious hyperchloremia and decreased anion gap in hyperlipidemia. Ann Intern Med. 1983;98(5 Pt 1):607-609.

7. Zimmer BW, Marcus RJ, Sawyer K, Harchelroad F. Salicylate intoxication as a cause of pseudohyperchloremia. Am J Kidney Dis. 2008;51(2):346-347

8. Faradji-Hazan V, Oster JR, Fedeman DG, Clerch AR, Perez GO. Effect of pyridostigmine bromide on serum bromide concentration and the anion gap. J Am Soc Nephrol. 1991;1(9):1123-1125.

9. Vigilance Canada. 2019. https://cvp-pcv.hc-sc.gc.ca/arq-rei/index-eng. jsp. Accessed August 132019.

10. Trump DL, Hochberg M. Bromide intoxication. Johns Hopkins Med J. 1976;138:119-123.

11. James LP, Farrar HC, Griebel ML, Bates SR. Bromism: intoxication from a rare anticonvulsant therapy. Pediatr Emerg Care. 1997; 13(4):268270.

12. Vasuvattakul S, Lertpattanasuwan N, Vareesangthip K, Nimmannit S, Nilwarangkur S. A negative anion gap as a clue to diagnose bromide intoxication. Nephron. 1995;69(3):311-313.

Publisher's Note: Springer Nature remains neutral with regard to jurisdictional claims in published maps and institutional affiliations. 